\title{
AN ANALYSIS OF MODALITY IN STUDENTS' HORTATORY EXPOSITION TEXTS (SYSTEMIC FUNCTIONAL GRAMMAR PERSFECTIVE)
}

\author{
Dian Ardiansah \\ English Language and Education Program \\ Galuh University of Teacher and Education Sciences Faculty \\ E-mail: Ardhy079@gmail.com
}

\begin{abstract}
This study deals with the interpersonal meaning revealed the use of modality system in students' hortatory exposition text at one of universities in Ciamis. Five texts of students' hortatory exposition were analyzed to find out what types of modality are used and what interpersonal meaning which is contained through modality system. This study employed Systemic Functional Grammar (SFG) based on Halliday and Matthiessen's (2004) framework since it can seek and identify the level of language structured which makes kinds of meaning.The findings showed that all of clauses which contained modality system indicated author's interpersonal meaning with different value of language in the texts. The different types of language value and polarity also indicated the author's interpersonal meaning in the texts. In addition, this analysis concluded that five texts comparised several modalization and modulation types which appeared with different ranks.
\end{abstract}

Keywords: Hortatory exposition text, interpersonal meaning, SFG, modality

\begin{abstract}
Abstrak
Penelitian ini berkenaan dengan makna interpersonal yang terungkap dari penggunaan sistem modalitas dalam teks eksposisi hortatory mahasiswa di salah satu universitas di Ciamis. Lima teks eksposisi hortatory mahasiswa dianalisis untuk mengetahui apa jenis modalitas yang digunakan dan apa makna interpersonal yang terkandung melalui sistem modalitas. Penelitian ini menggunakan Grammar Fungsional Sistemik (SFG) berdasarkan kerangka Halliday dan Matthiessen (2004) karena kerangka tersebut dapat mengidentifikasi tingkat bahasa terstruktur yang membuat berbagai jenis makna. Temuan penelitian ini menunjukkan bahwa semua klausa yang berisi sistem modalitas mengandung makna interpersonal penulis dengan nilai bahasa dalam teks yang berbeda. Berbagai jenis nilai bahasa dan polaritas juga menunjukkan makna interpersonal penulis dalam teks. Selain itu, penelitian ini menyimpulkan bahwa kelima teks memiliki beberapa tipe modalization dan modulasi yang muncul dengan peringkat yang berlainan.
\end{abstract}

Kata kunci: Hortatory exposition text, makna interpersonal, modalitas, SFG, 



\section{INTRODUCTION}

Writing can be one of the most enjoyable and satisfying activities for teachers and students to do together in a classroom, especially in learning English as foreign language. For many students, writing is very difficult.Hyland (2003, p. 3) states that writing is an intricate structure that can only be learned by developing the ability to manipulate lexis and grammar. It means writing in English language regarded an extension of grammar and vocabulary, reinforcing means language patterns through habit formation and measure students' ability to produce a good formed sentences.

Therefore, the importance of developed a students' in creative writing for academic purposes that served the purposes of EFL in English program. In addition, one of text that should be mastered by the students' in EFL class is hortatory exposition text. Hortatory exposition text is the type of the text to persuade someone to take some more action (Athanasopoulos \& Sandford, 1997 as cited in Lestari, et al. 2012, p. 4). Moreover, Nurhayati and Aswandi (2014, p. 25) argues that hortatory exposition text is a type of written or spoken text which explains to the readers or listeners about an issue should or should not happen by presenting one side of an issue with oneside argument to persuade them.

In this study, we analyzed the use of modality types in students' hortatory exposition text. Palmer (2001, p. 236) writes that "modality as a valid cross language grammatical category, along with tense and aspect, is notionally concerned with the event or situation that is reported by an utterance". Moreover, Halliday and Mathhiessen (2004, p. 148) argue that modality is an expression of indeterminacy. It can be expected that the systems of modality can describe interpersonal meaning of the text.

Analyze of modality in hortatory exposition text that able to know students' personal feelings, judgments, beliefs or knowledge with regard to certain propositions. Moreover, an interpersonal meaning describes grammatical structures and certain words do not always make the same meaning in the text (Bloor \& Bloor, 2004, p.10). In addition, we used systemic functional grammar perspective, because this study primarily studies about how language which is explores both how people use language and how language is structured for use as semiotic system (Eggins, 2004, p. 21).Based on the background above, this paper investigatedthe types of modality in students' hortatory exposition texts and figure out the interpersonal mening which is revealed through the use of modality in the texts.

The terms of Systemic Functional Grammar (SFG) is firstly introduced by M.A.K. Halliday in 1994. He assumed that "there can be no such thing as a 'complete' account of the grammar of language, because language is inexhaustible". Therefore, Halliday also presented a "conceptual framework" that based on its "functional one rather than formal one". According to Halliday (1994, p. 39), "It is functional in three distinct although closely related senses: in its interpretation. First, of texts, second, of the system, and third, of the elements of linguistic structure".Halliday and Matthiessen (2004, p.47) argues that systemic grammar is one which is organized around the concept of grammaticalization, whereby meaning is construed in networks of interrelated contrasts. In this research, a systemic functional grammar (SFG) framework 
used by we in analyzed of students' hortatory exposition text. On the other hand, Eggins (2004, p. 111) states that "Systemic grammar accounts for how language is structured for people to use to make kinds of meaning". It means that functional grammar copes with how people utilize it in diverse matter.

The idea of metafunction is emerged due to the development of functional grammar. Martin and Rose (2007, p. 4, 7) write there are exactly "three general functions of language in social contexts, there are to enact our relationships, to represent our experience, and to organize discourse as meaningful text". Those three general functions are called metafunction, there included ideational, interpersonal, and textual metafunction. According to Eggins (2004, p. 11) she states that metafunction of language represents the purpose of language. It means language make meaning. The linguistic in texts make a number of meanings simultaneously. Halliday and Matthiessen (2004, p. 29) suggested that metafunction is making sense of our experience, and acting out our social relationships. It is clear that language construing them into things and typically then construe human experience.Halliday put three metafunction namely interpersonal, textual and experiential. In this study, we only focuses on the interpersonal metafunction. Interpersonal meatafunction as another mode in describe of meaning which is related to the construction of text. In other sense, interpersonal metafunction regarded as an enabling or facilitating function, since construing experience and enacting interpersonal relations.

Halliday and Matthiessen (2004, p. 30) assume that interpersonal metafunction, is to suggest that it is both interactive and personal. Moreover, Hartyan (2011, p. 262) states interpersonal metafunction in the text is degree of intimacy or distance and the type of the relationship betweenwe and reader or participants in a text through the type of modality. Interpersonal metafunction has two important components: mood and modality. Eggins (2004, p. 147) writes that Mood structure consists of mood element and residue and Modalityis a complex area of an English grammar which investigates how to convey the message of the text, and residue is the element left over of the function the clause. In interpersonal analysis, meaning is considered from the point of view of its function in the process of social interaction. In the interpersonal metafunction, a clause is analysed into Modality. Nauze (2008, p. 1) states that modality is a broad category embracing many different interpretative typesthat can be expressed by many different constructions.

\section{METHOD}

This study concerns the analysis of modality used in the texts. We only focused on what types of modality used by the students in their hortatory exposition texts, and what interpersonal meaning is revealed through the use of modality in the texts. Gerot \& Wignell (1994, p. 28) state that modality represents the interpersonal meaning since it indicates the speakers judgement of the probabilities or the obligations involved in what he or she is saying.Matthews (2005, p. 228) defines modality as "category covering either a kind of speech act or the degree of certainty with which something is said". Moreover, Eggins (2004, p. 172) writes that modality is a complex area of an English grammar which investigates how to convey the message of the text, and how human express their attitudes and 
judgements through different ways. Furthemore, Halliday and Matthiessen (2004, p. 143) write that modality as the speaker's judgement, or request of the judgement of the listener, on the status of what is being said. From the definition above, modality is generally defined as a means of expressing the relationship between a speaker and an utterance, in a stricter sense a speaker and the truth-value of an utterance.

As one of the SFL tools, modality also has a system. Halliday and Matthiessen (2004, p. 147) divided it into two terms, they are propositions and proposals which are also known as modalizations and modulations. Halliday and Matthiessen (2004, p. 7) state that modalizations involve the expression of intermediate possibilities; first, degrees of probability (possibly/probably/certainly), second, degrees of usuality (sometimes, usually, always). Eggins (2004, p. 172) defines the terms of probability and usuality as follows the speaker expresses judgements as to the frequency in which something happens. Furthermore, Eggins (2004, p. 173) argues that modal adjuncts and modal operators can also be categorized into three values of certainty or usuality; first, in high: must, certainly, always, etc. Second, in median: may, probably, usually, etc. Third, low: might, possibly, sometimes, etc.

Related to this study, modality in the texts is selected the character of the author which is indicates several implications, such as judgments and command as interpersonal meaning. In addition, modality system in the texts can be power of language used by the author in the texts. Connected in this study, hortatory exposition text was one of method in creative writing subject at college as well one method in improving student ability in writing skill. In several texts, such as hortatory exposition text, it easier to find modality system in texts. Thus, modality in the text generally means expressing interpersonal meaning between the author and the readers through truthvalue of modality in the texts.

\section{RESULTS AND DISCUSSION}

In the process of analysing interpersonal meaning, we analyzed the texts by existence of modality types, value of modality, and polarity system which is contained in the sentence. The values were categorized in high, medium, and low. Then the polarity of the text will be positive and negative. It means the value of modality type and polarity analysis can be described the author meaning and how strong the statements or statements the author in the text. In addition, the types of modality were categorized by modalization and modulation with the topic "The Disadvantages of Using a Mobile Phone in Teaching Learning Process".

In the texte 1 , we found one type of epistemic modality which used by the author in the first text. Besides, the degree and polarity system of modality were focused to describe the interpersonal meaning of the text. 
Table 1: Data analysis of text 1

\begin{tabular}{|c|c|c|c|}
\hline Type & Clause & Degree & Polarity \\
\hline \multirow{3}{*}{ Probability } & The lecture canbe angry.\#4 & Median & Negative \\
\hline & $\begin{array}{l}\text { [[Using mobile]] phone } \text { can disturb } \\
\text { teaching learning process. \#7 }\end{array}$ & Median & Negative \\
\hline & $\begin{array}{l}\text { [[Using mobile phone] ]really disturb } \\
\text { teaching and learning process. \#8 }\end{array}$ & Median & Negative \\
\hline
\end{tabular}

The next result, we also found one type of deontic modality in the first text.

\begin{tabular}{clcc}
\hline Type & \multicolumn{1}{c}{ Clause } & Degree & Polarity \\
\hline Obligation & $\begin{array}{l}\text { The school should } \text { ban students[[to bring } \\
\text { their mobile phone to school]]. \#11 }\end{array}$ & Median & Positive \\
\hline
\end{tabular}

In the text two, we found one type of modalization(probability) and two types of modulation (obligation, and inclination)

Table 2: Data analysis of text 2

\begin{tabular}{|c|c|c|c|}
\hline Type & Clause & Degree & Polarity \\
\hline \multirow{9}{*}{ Probability } & $\begin{array}{l}\text { [[Using mobile phone }]] \underline{\text { can }} \text { disturb teaching } \\
\text { learning process. \#4 }\end{array}$ & Median & Negative \\
\hline & $\begin{array}{l}\text { The ringtone of mobile phone } \underline{c a n} \text { make a } \\
\text { noisy. \#5 }\end{array}$ & Median & Negative \\
\hline & $\begin{array}{l}\text { Itcan disturb the lecturer[[when he } \\
\text { explainsabout the material.]] \#6 }\end{array}$ & Median & Negative \\
\hline & $\begin{array}{l}\text { Itcan decrease the effectiveness of teaching } \\
\text { and learning process. \#8 }\end{array}$ & Median & Negative \\
\hline & $\begin{array}{l}\text { [[Using mobile phone]] make the lecture } \underline{c a n} \\
\text { get angry. } \# 9\end{array}$ & Median & Negative \\
\hline & $\begin{array}{l}{[[\text { As the punishment, }]] \text { the lecture will take }} \\
\text { mobile phone and destroy it. } \# 12\end{array}$ & Median & Negative \\
\hline & $\begin{array}{l}\text { The lecture also } \underline{c a n} \text { scold the students with } \\
\text { harsh word. } \# 13\end{array}$ & Median & Negative \\
\hline & Itcan disturb. \#15 & Median & Negative \\
\hline & The lecture can get angry. \#15 & Median & Negative \\
\hline
\end{tabular}

From the second text, we found so many 'probability' in the text. The next result was deontic modality which was found in the second the text. The result of modulation as deontic modality can be seen below:

\begin{tabular}{clcc}
\hline \multicolumn{1}{c}{ Type } & \multicolumn{1}{c}{ Clause } & Degree & Polarity \\
\hline & $\begin{array}{l}\text { [[Using mobile phone]] for students should be } \\
\text { confined. \#3 }\end{array}$ & Median & Positive \\
\cline { 2 - 4 } Obligation & $\begin{array}{l}\text { [[Using mobile phone in the teaching learning } \\
\text { process]] should not be allowed. \#14 }\end{array}$ & Median & Positive \\
\cline { 2 - 4 } & $\begin{array}{l}\text { The lecture should make a role [[to prohibit } \\
\text { all students [[to use mobile phone during } \\
\text { teaching and learning process.]] b]]a \#16 }\end{array}$ & Median & Positive \\
\end{tabular}


In the text three, we found the types of epistemic modality and deontic modality in the third text. The modalization type which found in text three are (probabilityand usuality). The result of modalization can be seen below:

Table 3: Data Analysis of text 3

\begin{tabular}{|c|c|c|c|}
\hline Type & Clause & Degree & Polarity \\
\hline \multirow{6}{*}{ Probability } & $\begin{array}{l}\text { [[Using mobile phone]] makes the students } \\
\text { unable [[to concentrate.]] \#3 }\end{array}$ & High & Negative \\
\hline & $\begin{array}{l}\text { [[Using mobile phone during teaching and } \\
\text { learning process]] can disturb the other } \\
\text { students. \#4 }\end{array}$ & Median & Negative \\
\hline & $\begin{array}{l}\text { [[Speaking loudly [[When receiving a calls,]] } \\
\text { b]]a it } \underline{\text { can make disturb teaching learning }} \\
\text { process]]. \#6 }\end{array}$ & Median & Negative \\
\hline & $\begin{array}{l}\text { [[Using mobile phone in teaching and learning } \\
\text { process]] can make the lecture get angry. \#7 }\end{array}$ & Median & Negative \\
\hline & $\begin{array}{l}\text { It is possible [[that the lecture not only get } \\
\text { angry.]] \#9 }\end{array}$ & Median & Negative \\
\hline & $\begin{array}{l}\text { The lecture } \underline{\text { can }} \text { make the students get out from } \\
\text { the class. } \# 11\end{array}$ & Median & Negative \\
\hline Usuality & $\begin{array}{l}\text { We often see lots of students [[using a mobile } \\
\text { phone during teaching and learning process.]] } \\
\# 1\end{array}$ & High & Negative \\
\hline
\end{tabular}

Furthermore, we also found deontic modality in the text. In addition, the type of deontic modality (modulation) which is used by the author is (obligation). The result of modulation as deontic modality can be seen below:

\begin{tabular}{clcc}
\hline Type & \multicolumn{1}{c}{ Clause } & Degree & Polarity \\
\hline Obligation & $\begin{array}{l}\text { The students should } \text { respect the other friends } \\
\text { and also the lecture in order [[to get the best in } \\
\text { teaching and learning process in the class.]] \#14 }\end{array}$ & Median & Positive \\
\hline
\end{tabular}

In the text four, we found one type of modalization (probability) which is categorized as epistemic modality. Moreover, one type of modulation (obligation)which is categorized as deontic modality also found in the fourth text. The result can be seen below: 
Table 4: Data Analysis of text 4

\begin{tabular}{|c|c|c|c|}
\hline Type & Clause & Degree & Polarity \\
\hline \multirow{5}{*}{ Probability } & $\begin{array}{l}\text { Some students think mobile phone } \underline{c a n} \\
\text { help them in any situation. } \# 4\end{array}$ & Median & Positive \\
\hline & $\begin{array}{l}\text { There are will be happened [[if they } \\
\text { using a mobile phone in teaching } \\
\text { learning process.]] \#5 }\end{array}$ & Median & Negative \\
\hline & $\begin{array}{l}\text { Another students will be not focus about } \\
\text { the material. \#8 }\end{array}$ & Median & Negative \\
\hline & $\begin{array}{l}\text { The lecture can get angry [[when } \\
\text { students using mobile phone in teaching } \\
\text { learning process.]] } \# 11\end{array}$ & Median & Negative \\
\hline & $\begin{array}{l}\text { The lecture will be taken their mobile } \\
\text { phone. } \# 13\end{array}$ & Median & Negative \\
\hline
\end{tabular}

From table above, we found one type of epistemic modality which used by the author in the first text. Besides, the value and polarity system of modality were focused to describe the interpersonal meaning of the text. The next result, the researcher also found deontic modality type in the text. The result can be seen below:

\begin{tabular}{clcc}
\hline Type & \multicolumn{1}{c}{ Clause } & Degree & Polarity \\
\hline \multirow{3}{*}{ Obligation } & $\begin{array}{l}\text { The most important think is [[students } \\
\text { should } \text { not using mobile phone when }\end{array}$ & Median & Positive \\
& $\begin{array}{l}\text { teaching learning process.]] \#13 } \\
\text { When teaching learning process, mobile } \\
\text { phone should be off or silent. \#17 }\end{array}$ & Median & Positive \\
& & & \\
&
\end{tabular}

In the text 5, we found two types of modalization (probability, and usuality) which are categorized as epistemic modality and two types of modulation (obligation) which are categorized as deontic modality in the last text. The result can be seen below:

Table 5: Data Analysis of text 5

\begin{tabular}{|c|c|c|c|}
\hline Type & Clause & Degree & Polarity \\
\hline \multirow{5}{*}{ Probability } & $\begin{array}{l}\text { Mobile phone } \text { can disturb teaching and } \\
\text { learning process. } \# 5\end{array}$ & Median & Negative \\
\hline & $\begin{array}{l}\text { Mobile phone } \underline{\text { can }} \text { disturb their focus } \\
\text { [[when they are concentrating to the } \\
\text { teacher.]] \#7 }\end{array}$ & Median & Negative \\
\hline & $\begin{array}{l}\text { The students will lost their concentration } \\
{[[\text { when the phone ringing. }]] \# 8}\end{array}$ & Median & Negative \\
\hline & $\begin{array}{l}\text { They will not watch and listen [[what their } \\
\text { teacher said [[when their phone ringing.]] } \\
\text { b]]a \#9 }\end{array}$ & Median & Negative \\
\hline & The lecture can get angry. \#15 & Median & Negative \\
\hline
\end{tabular}




\begin{tabular}{|c|c|c|c|}
\hline & $\begin{array}{l}\text { The phone ringing will also stop the } \\
\text { learning process in the class. \#16 }\end{array}$ & Median & Negative \\
\hline & $\begin{array}{l}\text { The lecture and the students will change } \\
\text { their mind to the phone [[because it rings } \\
\text { on the middle of learning process.]] \#17 }\end{array}$ & Median & Negative \\
\hline & The class will not run well. \#18 & Median & Negative \\
\hline & The students may become side-tracked.\#21 & Low & Negative \\
\hline & $\begin{array}{l}\text { The teacher } \underline{\text { may }} \text { be interrupted [[while } \\
\text { speaking in the class.]] \#22 }\end{array}$ & Low & Negative \\
\hline & $\begin{array}{l}\text { Mobile phone will be useless [[if the } \\
\text { students bring it to the school.]] \#24 }\end{array}$ & Median & Negative \\
\hline Usuality & $\begin{array}{l}\text { The students often bring it everywhere they } \\
\text { go. \#2 }\end{array}$ & High & Positive \\
\hline
\end{tabular}

From the text, we found so many 'probability' in the text. The next result was deontic modality which was found in the second the text. The result of modulation as deontic modality can be seen

below:

\begin{tabular}{|c|c|c|c|}
\hline Type & Clause & Degree & Polarity \\
\hline Obligation & $\begin{array}{l}\text { We must also bore the responsibility of not } \\
\text { letting them become tools of disruption. } \\
\# 26\end{array}$ & High & Positive \\
\hline
\end{tabular}

This section encompasses the result of modality analysis in the text entitled "The Disadvantages of Using Mobile Phone in Teaching and Learning Process".
Then, we also gave the rank of modality (modalization and modulation) types which are used by the students in the texts. The result of text 1 can be seen below:

Table 6: The rank of modality (modalization and modulation)

\begin{tabular}{|c|c|c|c|c|}
\hline \multirow[t]{2}{*}{ Rank } & \multicolumn{2}{|c|}{ Modalization } & \multicolumn{2}{|c|}{ Modulation } \\
\hline & Probability & Usuality & Obligation & Inclination \\
\hline \multicolumn{5}{|l|}{ High } \\
\hline Median & 3 & & 1 & \\
\hline
\end{tabular}

From the table above, in answering the first research question, it can be seen that the author involved two words of probability (really) in high value, two words of probability (can, can) in median value. The last is obligation (should) in median value as modulation in the first text.

To answer the second research question about the interpersonal meaning, the first text contained more judgments through modalization type from the author's to the readers, i.e. that the used of mobile phone during teaching and learning process has so many disadvantages than the advantages. In the first text, the author more judge the students to not use mobile phone during teaching and learning. Besides, modulation type can be described about suggested or commands by the author to the readers, especially to the teacher to give the role or ban the students not to use mobile phone in school. Related to the theory, Gerot \& Wignell (1994, p. 
28) state that modality represents the interpersonal meaning since it indicates the speakers 'judgement of the probabilities or the obligations involved in what he or she is saying. Through the value modality system; it is described how strong language used in the text. The polarity described what meaning from the author's used in the text. For the next result, we were shown the result of modality analysis in text 2 . The result can be seen below:

Table 7: The result of modality analysis in text 2

\begin{tabular}{l} 
Rank \begin{tabular}{l} 
Modalization \\
\cline { 2 - 2 } High
\end{tabular} Probability Usuality \\
\hline Median \\
Fow \\
From the table above, in answering \\
the first research question, it can be seen \\
that the author only involved the type of \\
probability (will) in median value, and \\
(can, can, can, can, can, can, can, can) in \\
median value, and three words of deontic \\
modality (should, should, should) in \\
median value as the type of modality in \\
second text. \\
To answer the second research \\
question about the interpersonal meaning, \\
the second text contained more judgments \\
through modalization type from the \\
author's to the readers, the type of \\
modalization dominated by probability \\
type. It can be concluded that probability \\
type dominated judgments in median value \\
in second text, i.e. the author's judge that \\
the used of mobile phone during teaching
\end{tabular}

Modulation

\begin{tabular}{ll} 
Obligation & Inclination \\
\hline 3 & \\
\end{tabular}

and learning process has so many disadvantages than the advantages. In the second text, the author more judge the students to not use mobile phone during teaching and learning. Besides, modulation type can be described about suggested or commands by the author to the readers, especially to the teacher to give the role or ban the students not to use mobile phone in school. Through the value modality system; it is described how strong language used in the text. The polarity described what meaning from the author's used in the text. Matthews (2005, p. 228) defines modality as "category covering either a kind of speech act or the degree of certainty with which something is said".For the next result, we were shown the result of modality analysis in text 3 . The result can be seen below:

Table 8: The result of modality analysis in text 3

\begin{tabular}{|c|c|c|c|c|}
\hline \multirow[t]{2}{*}{ Rank } & \multicolumn{2}{|c|}{ Modalization } & \multicolumn{2}{|c|}{ Modulation } \\
\hline & Probability & Usuality & Obligation & Inclination \\
\hline High & 1 & 1 & & \\
\hline Median & 5 & & 1 & \\
\hline \multicolumn{5}{|l|}{ Low } \\
\hline $\begin{array}{l}\text { Fron } \\
\text { the first res } \\
\text { that the a } \\
\text { probability }\end{array}$ & $\begin{array}{l}\text { table above, } \\
\text { question, } \\
\text { involved } \\
\text { ble) in hig }\end{array}$ & $\begin{array}{l}\text { swering } \\
\text { be seen } \\
\text { ypes of } \\
\text { ue, and }\end{array}$ & $\begin{array}{l}\text { (can, can, } \\
\text { value, and } \\
\text { (should) in } \\
\text { modality in }\end{array}$ & $\begin{array}{l}\text { possible, } \\
\text { word of de } \\
\text { dian value } \\
\text { nd text. }\end{array}$ \\
\hline
\end{tabular}


To answer the second research question about the interpersonal meaning, the third text contained several judgments from the author's to the readers, i.e. the author's judge that the used of mobile phone during teaching and learning process has disadvantages than the advantages. In the second text, the author judge the students to not use mobile phone during teaching and learning. Besides, modulation type can be described about suggested or commands by the author to the readers, especially to the students to respect other students in teaching and learning process. Halliday and Matthiessen
(2004, p. 143) write that modality as the speaker's judgement, or request of the judgement of the listener, on the status of what is being said. From the definition above, modality is generally defined as a means of expressing the relationship between a speaker and an utterance, in a stricter sense a speaker and the truth-value of an utterance. Through the value modality system; it is described how strong language used in the text. The polarity described what meaning from the author's used in the text. For the next result, we were shown the result of modality analysis in text 4 . The result can be seen below:

Table 9: The result of modality analysis in text 4

\begin{tabular}{|c|c|}
\hline Modalization & Modulation \\
\hline Probability & Inclination \\
\hline High & \\
\hline Median & 2 \\
\hline Low & \\
\hline $\begin{array}{l}\text { From the table above, in answering } \\
\text { the first research question, it can be seen } \\
\text { that the author involved the types of } \\
\text { probability (will, will, will) in median } \\
\text { value, and (can, can) in median value, and } \\
\text { one word of deontic modality (should, } \\
\text { should) in median value as the type of } \\
\text { modality in text four. }\end{array}$ & $\begin{array}{l}\text { types of obligation indicated that the } \\
\text { author's also gives suggestion and } \\
\text { command to the students as readers target } \\
\text { in this text. The polarity described what } \\
\text { meaning from the author's used in the text. } \\
\text { Halliday and Matthiessen ( } 2004, \text { p. 147) } \\
\text { describe that modality is the system that } \\
\text { can interpret a message behind "yes" or } \\
\text { "no". the middle position amid positive }\end{array}$ \\
\hline $\begin{array}{l}\text { Through this analysis of text four, } \\
\text { all of the clauses that indicated the } \\
\text { interpersonal meaning through modality } \\
\text { system in this text. In this text, we found } \\
\text { three probability types in high value, i.e. } \\
\text { that the author was strongly sure in her } \\
\text { judgments which reveals the text. Two }\end{array}$ & $\begin{array}{l}\text { and negative. It can be concluded that } \\
\text { modality is an expression of the speaker's } \\
\text { or author's opinion which made other } \\
\text { sense of interpersonal meaning. For the } \\
\text { next result, we were shown the result of } \\
\text { modality analysis in text } 5 \text {. The result can } \\
\text { be seen below: }\end{array}$ \\
\hline
\end{tabular}


Table 10: The result of modality analysis in text 5

\begin{tabular}{l}
\hline Rank \\
\cline { 2 - 2 } High \\
\hline Median \\
\hline Low \\
\hline From the table above, in answer the \\
\hline first research question, it can be seen that \\
the author involved the types of \\
probability (will, will, will, will, will) in \\
median value, and (can, can,can) in \\
median value, and two in low value (may, \\
may), one type usuality in high value \\
(often) as modalization type.Moreover, the \\
researcher also found the words \\
(important, important, must, important) as \\
obligation type and one type in inclination \\
(prefer) as modulation.
\end{tabular}

In addition, interpersonal meaning in the last text definite the type of modalization indicates the written is judge to not use mobile phone in teaching and learning process, the value in the text defined that the author strongly sure in her judgments; it is because the value dominated in high value in probability type. Hartyan (2011, p. 262) states interpersonal metafunction in the text is degree of intimacy or distance and the type of the relationship betweenwe and reader or participants in a text through the type of modality.Modulation type represented weather something is do not allowed to do. From this text, we also gives suggested or commands the readers through modulation system in the text, especially to the students as target readers. In other word, modulation type represented whether something is allowed to do.

Through this analysis, it can be concluded that all of texts comprised several types of modality informs of modalization and modulation which appeared with different ranks and polarity, and modality system also reveals interpersonal meaning.In addition, Fintel (2006, p. 1) states that modality is a category of linguistic meaning having to do with the expression of possibility and necessity. According to modality and the sentences all of the types, value and polarity of modality system indicated the author's interpersonal meaning to the others or readers through modality system in this text.

\section{CONCLUSION}

The analysis results show that two types of modality founded in the texts. In addition, the type of modality dominated by epistemic modality, we found so many words of 'can' as probability type in texts. The use of modality system indicates that the interpersonal meaning was still related to modality system. In addition, the type of modalization as epistemic modality in the texts more indicated the author's judgments about disadvantages of using mobile phone during teaching and learning. Halliday and Matthiessen (2004, p. 7) state that modalizations involve the expression of intermediate possibilities; first, rank of probability (possibly/probably/certainly), second, rank of usuality (sometimes, usually, always). Eggins (2004, p. 172) defines the terms of probability and usuality as follows the speaker expresses judgements as to the frequency in which something happens. Besides, the type of deontic modality in the texts indicated the author's command or guidelines, it means that not only disadvantages when the students use mobile phone in the class, but also the advantages too, such as browsing for information, and for searching the 
material. Thus, it can be seen that the value and polarity of modality indicated how strong the language reveals interpersonal meaning suggested by author. In addition, SFL in this study is also beneficial for the teachers who teach creative writing. With the use of modality system in the writing, the students can be able to more critically evaluate their own works and also understand that language also functions to make meaning. Accordingly, thisstudy is expected to improve the teachers in understanding of Systemic Functional Linguistic as the effective method in teaching writing.

\section{ACKNOWLEDGMENTS}

I would like to express my sincere gratitude to journal bahasa \& sastra for publishing this research article, and the same goes to those who have helped this research.

\section{REFERENCES}

Bloor, T., \& Bloor, M. (2004). The functional analysis of English: A Hallidayan approach ( $2^{\text {nd }}$ Ed.). London, UK: Arnold. Retrieved fromhttp://bookos.org/book/1443 022/a512d4

Eggins, S. (2004). An introduction to Systemic Functional Linguistics ( $2^{\text {nd }}$ ed.). London, UK: Continuum.

Fintel, K.V. (2006). Modality and Language. In D.M. Borchert ( $2^{\text {nd }}$ ed.). Detroit, US: MacMillan. Retrieved fromhttp://mit.edu/fintel/www/mo dality.pdf

Gerot, L., \& Wignell, P. (1994). Making sense of functional grammar: An introductory workbook. Australia: GerdStablerAntipodean EducationalEnterprises.
Halliday, M.A.K. (1994). Introduction to Functional Grammar $\quad\left(2^{\text {nd }}\right)$. London: Edward Arnold.

Halliday, M.A.K., \& Matthiessen, C.M.I.M. (2004). An introduction to functional grammar ( ${ }^{\text {rd }} \mathrm{Ed}$.). London, UK: Hodder Arnold.

Hartyan, F. (2011). Hallidays' SFL and social meaning: Historical and social sciences ( $2^{\text {nd }}$ ed.) $17,260-$ 264. Singapore: Lascit Press.

Hyland, K. (2003).Second language writing.In J.C. Richard (Eds.). General principle for L2 writing: Critical analysis. New York, NY: Cambridge University Press.

Lestari, H. Rumiri, R. Aruan., \& Hadrian. (2012). Students' ability in writing hortatory exposition text: $P Q P$ technique. Retrieved from http://repository.unri.ac.id/xmlui/ handle/123456789/878

Martin, J.R., \& Rose, D. (2007). Working with discourse: Meaning beyond the clause $\left(2^{\text {nd }}\right.$ Ed.). London, UK: Continuum.

Matthews, P.H. (2005). The oxford concise dictionary of Linguistics. Oxford: Oxford University Press.

Nauze, F.D. (2008). Modality in typological perspective. Amsterdam: ILLC press. Retrieved from http://www.illc.uva.nl/

Nurhayati, A., \& Aswandi. (2014). Implementing interactive reading model to teaching hortatory exposition text. Journal of UNESA, 01, 1-9.

Palmer, F.R. (2001). Mood and modality: Cambridge textbook in linguistic $\left(2^{\text {nd }}\right.$ ed.). New York, NY: Cambridge university press. 